\title{
Pericentric Intrachromosomal Insertion Responsible for Recurrence of del(II)(p/3p|4) in a Family
}

\author{
Isabelle Henry, Jan Hoovers, Fernande Barichard, Marie-Françoise Berthéas, Anne Puech, Fabienne Prieur, \\ Manfred Gessler, Gail Bruns, Marcel Mannens, and Claudine Junien
}

IN.S.E.R.M. U73, Chåteau de Longchamp, Bois de Boulogne, Paris, France (I.H., F.B., A.P., C.I); Institute of Human Genetics, Faculty of Medicine. Academic Medical Centre, University of Amsterdam. Amsterdam. The Netherlands (J.H., M.M.); Unité de cytogénétique. CHRU Saint-Etienne, France (M.-F.B., F.P.): Institut für Humangenetik \& Humangenetische Poliklinik, Phillips-Universität, Marburg. Germany (M.G.): Department of Clinical Genetics. Children's Hospital, Boston, Massachusetts (G.B.)

The combined use of qualitative and quantitative analysis of $1 / \mathrm{p} / 3$ polymorphic markers together with chromosomal in situ suppression hybridization (CISS) with biotin labeled probes mapping to $\| \mathrm{p}$ allowed us to characterize a complex rearrangement segregating in a family. We detected a pericentric intrachromosomal insertion responsible for recurrence of $\operatorname{del}(I I)(\mathrm{p}|3 \mathrm{p}| 4)$ in the family: an insertion of band IIp/3-p/4 carrying the genes for predisposition to Wilms' tumor, WTI, and for aniridia, AN2, into the long arm of chromosome $1 /$ in $1 / q|3-q| 4$. Asymptomatic balanced carriers were observed over three generations. Classical cytogenetics had failed to detect this anomaly in the balanced carriers, who were first considered to be somatic mosaics for del(II)(p/3). Two of these women gave birth to children carrying a deleted chromosome II, most likely resulting from the loss of the $1 / \mathrm{p} / 3$ band inserted in $1 / \mathrm{q}$. Although in both cases the deletion encompassed exactly the same maternally inherited markers, there was a wide variation in clinical expression. One child, with the karyotype 46.XY, del(II)(p/3p/4), presented the full-blown WAGR syndrome with aniridia, mental retardation, Wilms' tumor, and pseudohermaphroditism, but also had proteinuria and glomerular sclerosis reminiscent of Drash syndrome. In contrast, the other one, a girl with the karyotype $46, X X, \operatorname{del}(\mid I)(p \mid 3)$, only had aniridia. Although a specific set of mutational sites has been observed in Drash patients, these findings suggest that the loss of one copy of the WTI gene can result in similar genital and kidney abnormalities. Genes Chrom Concer 7:57-62 (1993).

The WAGR syndrome is a contiguous gene syndrome associated with an interstitial deletion of band 11p13; it consists of Wilms' tumor (WT), aniridia (A), genitourinary abnormalities $(G)$, and mental retardation (R) (Francke et al., 1979). Band 11 p13 harbors a number of genes involved in the differentiation and growth control of the eye, kidney, and urogenital tract. Two candidate genes have been isolated recently. The first one, WT1, is a zinc finger gene with a proline/glutamine-rich region in the $\mathrm{N}$-terminal portion. It was isolated by positional cloning as a candidate Wilms' tumor predisposition gene and is now widely accepted as a tumor suppressor gene (Call et al., 1990; Gessler et al., 1990; Rose et al., 1990). Tumor specific and constitutional mutations have been described (Haber et al., 1990; Pelletier et al., 1991b). As shown by point mutations in WTI in patients with the triad glomerulopathy, Wilms' tumor, and ambiguous genitalia known as the Drash syndrome (Pelletier et al., 1991a), this gene participates in kidney and genitourinary development (PritchardJones et al., 1990; van Heyningen et al., 1990). For the second gene, $A N 2$, candidate sequences have also been cloned (Mannens et al., 1991; Ton et al., 1992; van Heyningen et al., 1992). Among these, the human homolog of the $P a x-6$ gene, which car- (c) 1993 Wiley-Liss, Inc.

ries the murine small eye mutations, corresponds to a transcription factor with a paired-box domain, a homeodomain, and a serine/threonine-rich carboxy-terminal domain. Different laboratories have constructed maps for $11 \mathrm{p} 13$ and numerous markers are available to study this part of chromosome 11 (Junien and van Heyningen, 1991).

Using $11 \mathrm{p} 13$ markers, we have characterized a rearrangement observed in a family with two onceremoved first cousins carrying $\operatorname{del}(11)(\mathrm{p} 13)$ associated with a complete WAGR syndrome in one case and isolated aniridia in the other. The differences in the clinical features for these two cases could be due either to incomplete penetrance of this syndrome, since $68 \%$ of the patients with del(11)(p13) and aniridia develop WT, or to a difference in the size of the deletion.

By genotyping, gene dosage analysis, and chromosomal in situ suppression hybridization (CISS) we determined the extent of the deletion in the two $\operatorname{del}(11)(\mathrm{p} 13)$ cases and identified the rear. ranged chromosome inherited from the transmitting individuals.

Received May 11, 1992; accepted August 31, 1992.

Address reprint requests to Dr. Claudine Junien, I.N.S.E.R.M. U73, Château de Longchamp, Bois de Boulogne, Paris, France. 


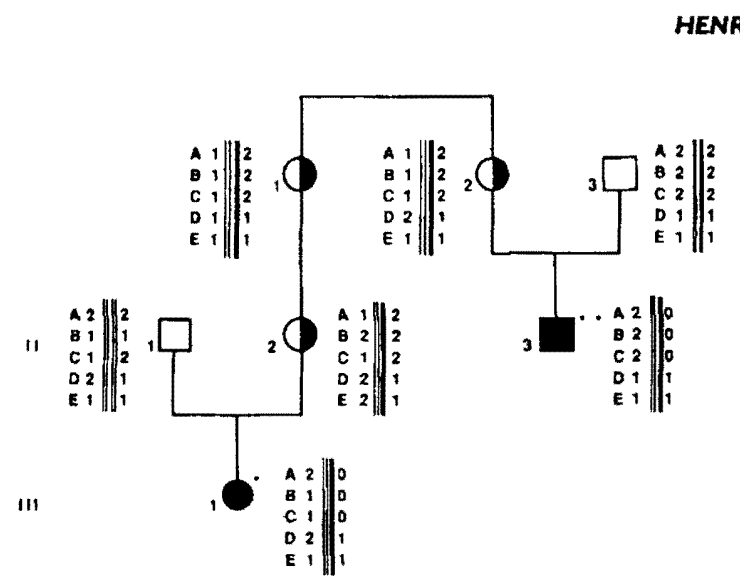

Figure 1. Pedigree and genotypes of the family. Alleles were named 1 and 2 according to decreasing length: $1 / 0$ or 210 means that the individual was deleted for one allele. $A=F S H B ; B=D|I S| 6 ; C=$ $D$ IIS324; $D=D$ IIS325; $E=D \mid 1 S 414$. For markers $A$ and $C$ only one of the four possible phases is displayed. ${ }^{*}=$ Patient presenting with $\operatorname{del}(\mid 1)(p \mid 3)$ and aniridia ${ }^{* *}=$ Patient presenting with del(II) $(p \mid 3)$. aniridia, genitourinary abnormalities, mental retardation, and Wilms' tumor.

The pedigree of the family is shown in Figure 1. Patient II3 had the karyotype 46,XY, del(11)(p13). A complete WAGR syndrome was present: aniridia, genitourinary abnormalities with pseudohermaphroditism stage $\mathrm{III}$, and mental retardation. The child had ambiguous external genitalia with a peno-clitoris and a vagina. There was no uterus. The right intraperitoneal gonad was a streak undefined gonad, whereas the left labioscrotal gonad resembled a testis. The child was raised as a girl because of the ambiguous genitalia. The patient developed a Wilms' tumor at age two, had moderate proteinuria starting in the neonatal period without kidney deficiency, and had glomerular sclerosis of the renal parenchyma. Patient IIII presented with aniridia but had no evidence of genitourinary abnormalities, mental retardation, or Wilms' tumor. The karyotype was $46, \mathrm{XX}$, del(11)(p13). No clinical features of the WAGR syndrome were observed in the obligate carriers $\mathrm{I} 1, \mathrm{I} 2$, and II 2 .

DNA was prepared from EBV-established lymphoblastoid cell lines. For gene copy number analyses the same Southern blots were successively hybridized with an $11 \mathrm{p} 13$ probe and with a nonchromosome 11 probe. The intensity of the hybridization signals was measured with a SEBIA densitometer. The value of the $11 \mathrm{p} 13$ probe versus non-11 internal control probe was calculated for each independent determination. A ratio of patient versus control close to 1 indicated that there were two copies of the marker in the DNA of the control individual and in the DNA of the patient, while a ratio close to 0.5 indicated that there were two copies of the marker in the DNA of the control individual and only one copy in the patient's DNA.

The probes used for Southern blot and in situ hybridization are listed in Table 1. Probes were localized by calculating FLpter values or relative to breakpoints (Hoovers et al., 1992). The order of D11S87, WT1, D11S324, FAT5, and ZnFP17 has been determined using molecular techniques (Junien and van Heyningen, 1991; Heding et al., 1992; Ton et al., 1992).

CISS hybridization was performed according to Lichter et al. (1990) but with the modifications described by Hoovers et al. (1992). Briefly, the cosmid probes were ethanol-precipitated in the presence of 50-500-fold concentration of total human DNA. After denaturation of the probe mixture at $70^{\circ} \mathrm{C}$, preannealing of repetitive DNA sequences was performed for 1 hour at $37^{\circ} \mathrm{C}$. The centromere-specific probe was denatured separately. FITC-conjugated avidin was used for the detection of biotinylated probes. When necessary, the signal was amplified, using biotinylated goatanti-avidin and a second layer of FITC-conjugated avidin.

For genotyping, DNA from individuals I1, I2, 13, II1, II2, II3, and IIII was digested with the appropriate enzymes and hybridized following Southern blot experiments, using $11 \mathrm{p} 13$ markers mapping in the following order: cen-D11S9-CATD11S414/D11S325-WT1-AN2-D11S323-D11S324D11S151-D11S16/D11S317-FSHB-tel (Junien and van Heyningen, 1991). The genotypes obtained are listed in Table 2. Only informative markers which allowed us to determine the haplotypic phases for $11 \mathrm{p} 13$ are represented in Figure 1. None of the patients inherited alleles from their mothers at loci FSHB (A), D11S16 (B), and D11S324 (C). Patients II3 and III1 inherited the same alleles for D11S325 (D) and D11S414 (E) from individual I1. Individuals I1, II1, and III1 inherited the same haplotype (D1-E1) for the D and E loci, showing that the deletion occurred on the same chromosome.

To determine the size of the deletions observed by cytogenetic and genetic analyses in patients II 3 and III1, the gene copy number was determined on the DNA of both patients, using probes D11S317, D11S151, CAT (data not shown), FSHB, D11S325, and D11S414 ('Table 3). COL1A1 was used as a non-11p internal control. Both patients had only one copy of the sequences corresponding to $F S H B$, D11S317, and D11S151 but displayed two copies of the sequences corresponding to 
TABLE I. Probes: Description and Localization of the Different IIp Probes Used for Chromosome In Situ Suppression Hybridization"

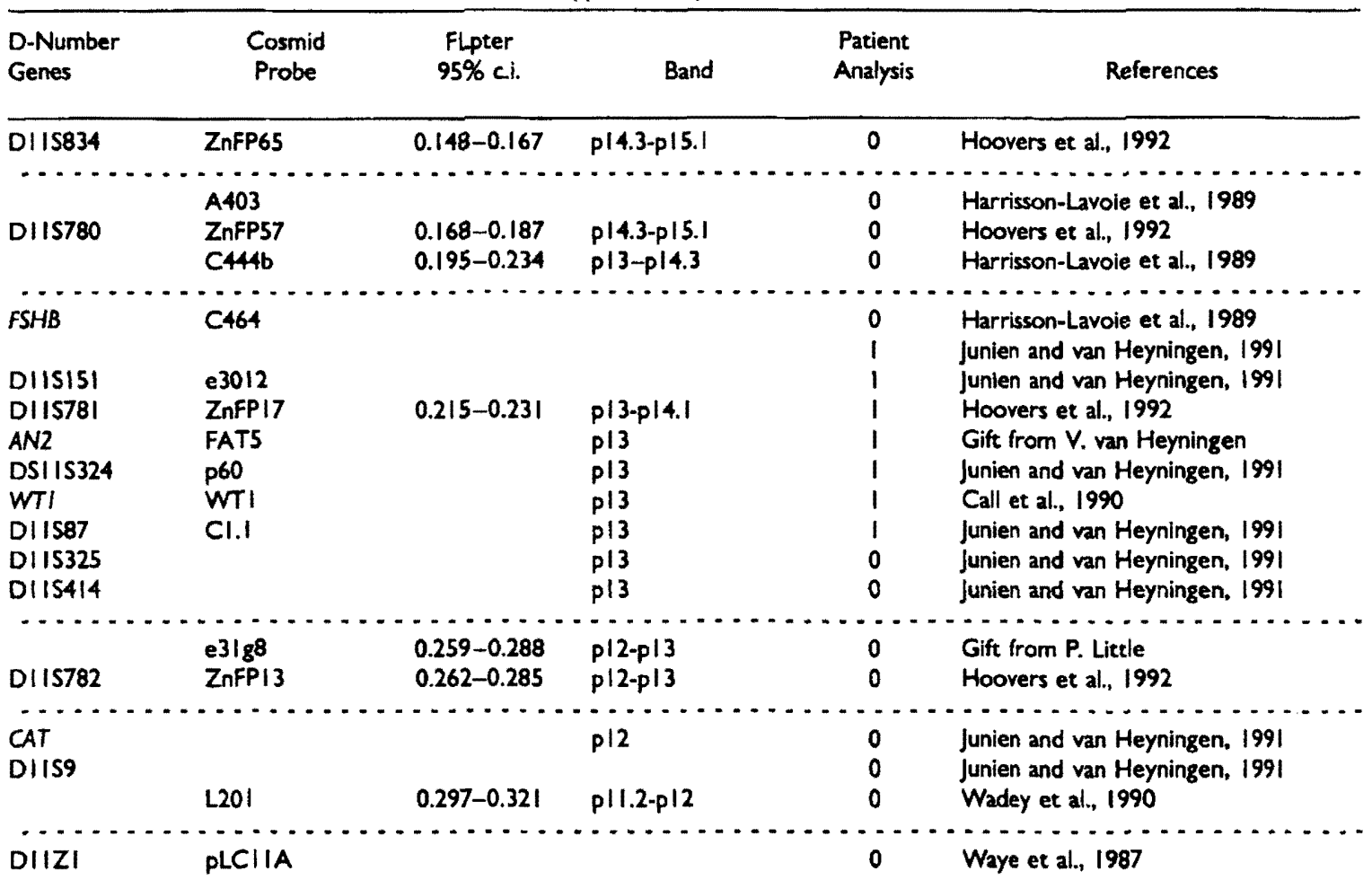

"Flpter = relative distance of the probe tested to pter, $c .1$. $=$ confidence interval; $I=$ probe is deleted/inserted; $0=$ probe is not deleted/inserted; $\ldots=$ chromosomal breakpoint known. When no Flpter values are given, the localization is based on cytogenetic banding studies.

TABLE 2. Genotypes of the Different Individuals"

\begin{tabular}{|c|c|c|c|c|c|c|c|c|c|c|}
\hline & $\begin{array}{c}\text { A } \\
\text { FSHB } \\
\text { Hindlll }\end{array}$ & $\begin{array}{c}\text { B } \\
\$ 16 \\
\text { Mspl }\end{array}$ & $\begin{array}{l}\text { SISI } \\
\text { Pstl }\end{array}$ & $\begin{array}{c}C \\
\text { S324 } \\
\text { Toql }\end{array}$ & $\begin{array}{l}\$ 323 \\
\text { Haell }\end{array}$ & $\begin{array}{c}D \\
\$ 325 \\
\text { BgIII }\end{array}$ & $\begin{array}{c}\text { S325 } \\
\text { HindIII }\end{array}$ & $\begin{array}{c}\text { E } \\
\text { S414 } \\
\text { Taql }\end{array}$ & $\begin{array}{l}S 414 \\
X m n !\end{array}$ & $\begin{array}{l}\text { CAT } \\
\text { Avall }\end{array}$ \\
\hline 11 & $1 / 2$ & $1 / 2$ & $2 / 2$ & $1 / 2$ & $2 / 2$ & $1 / 1$ & $2 / 2$ & $1 / 1$ & $1 / 1$ & $1 / 2$ \\
\hline 12 & $1 / 2$ & $1 / 2$ & $2 / 2$ & $1 / 2$ & $2 / 2$ & $1 / 2$ & $2 / 2$ & $1 / 1$ & $1 / 1$ & $1 / 2$ \\
\hline 13 & $2 / 2$ & $2 / 2$ & $2 / 2$ & $2 / 2$ & $2 / 2$ & $1 / 1$ & $2 / 2$ & $1 / 1$ & $1 / 1$ & $1 / 2$ \\
\hline III & $2 / 2$ & $1 / 1$ & $2 / 2$ & $1 / 2$ & $1 / 2$ & $1 / 2$ & $1 / 2$ & $1 / 1$ & $1 / 1$ & $1 / 2$ \\
\hline 112 & $1 / 2$ & $2 / 2$ & $2 / 2$ & $1 / 2$ & $2 / 2$ & $1 / 2$ & $2 / 2$ & $1 / 2$ & $1 / 2$ & $1 / 2$ \\
\hline 113 & $2 / 0$ & $2 / 0$ & $2 / 0$ & $2 / 0$ & $2 / 0$ & $1 / 1$ & $2 / 2$ & $1 / 1$ & $1 / 1$ & $1 / 2$ \\
\hline IIII & $2 / 0$ & $1 / 0$ & $2 / 0$ & $1 / 0$ & $1 / 0$ & $1 / 2$ & $1 / 2$ & $1 / 1$ & $1 / 1$ & $1 / 2$ \\
\hline
\end{tabular}

"FSHB (A), S16 = DIISI6 (B), SISI =DIISISI, S324 =DIIS324 (C), S323 = DIIS323, S325 = DIIS325 (D), S414 = DIIS414 (E). Alleles were named $I$ and 2 according to decreasing length; $0=$ deleted allele.

D11S414, D11S325, and CAT. The deletions observed involved the same $11 \mathrm{p} 13$ markers from FSHB, at least, including D11S151 (Table 3; Fig. 2). With the markers used we were not able to define the distal breakpoints by gene dosage analysis.

Probe $\mathrm{Znfp} 17$ (D11S781) is specific for $11 \mathrm{p} 13$ and was used to perform in situ hybridization on metaphases obtained from the asymptomatic transmitting individuals 11,12 , and 112 and from the patients II 3 and III1. The sequence corresponding to $\mathrm{Znfp} 17$ was found to be transferred to the proximal long arm for one of the two homologous chromosomes 11 for individuals I1, I2, and I12 (Fig. 3A). In patients II 3 and III1, there was no signal corresponding to $\mathrm{Znfp} 17$ either on $11 \mathrm{p} 13$ or on 
TABLE 3. Gene Copy Number Determination, Densitometry Data"

\begin{tabular}{|c|c|c|c|c|c|c|c|c|c|c|c|c|}
\hline & \multicolumn{4}{|c|}{ FSHB Probe } & \multicolumn{4}{|c|}{ S325 Probe } & \multicolumn{4}{|c|}{ S414 Probe } \\
\hline & FSHB & COLIAI & $\mathbf{R}$ & $P / C$ & S325 & COLIAI & $\mathbf{R}$ & P/C & 5414 & COLIAI & $\mathbf{R}$ & $P / C$ \\
\hline CONTROL & 276 & 164 & 1.68 & & 893 & 573 & 1.56 & & 1,709 & 1,068 & 1.60 & \\
\hline IIII & 192 & 188 & 1.02 & 0.60 & 605 & 411 & 1.47 & 0.94 & 1,812 & 1,135 & 1.59 & 0.99 \\
\hline$\| 3$ & 105 & 94 & 1.11 & 0.66 & 803 & 441 & 1.82 & 1.16 & 1,823 & 952 & 1.91 & 1.19 \\
\hline
\end{tabular}

Densitometry values obtained by scanning the blozs shown in Figure $2 . R=$ ratio obtained by dividing the intensity for the ||$p \mid 3$ marker by the intensity of the non-1 Ip internal control (COLIAI); P/C = ratio obtained by dividing the preceding ratio for the patient by that of the control individual; S325 = DIIS325; S4I4= DIIS4I4.

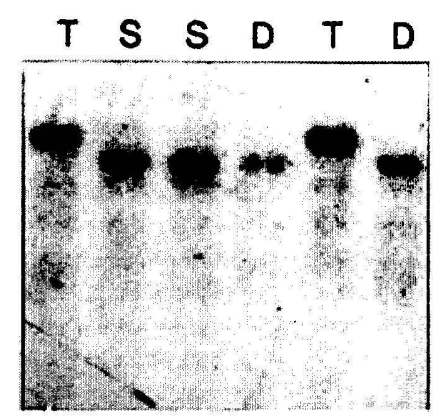

FSHB / Hind III

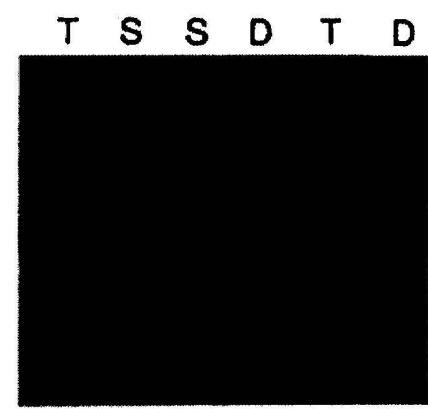

COL1A1/ Hind III

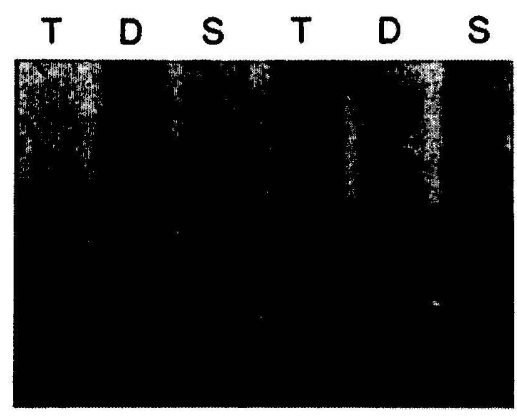

DIIS325 / Hind III

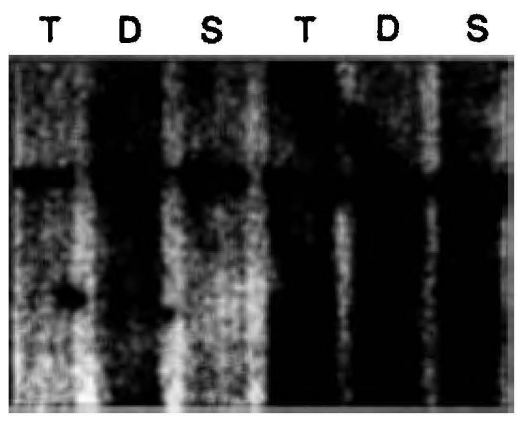

COL1A1 / Hind III

Figure 2 Gene copy number determination for patients II 3 and IIII. Top: I I | 3 probes: FSHB and DI IS325. Bottom: The same filters were hybridized with 2 non- $I I p$ probe, COLIAI, used as the internal control. Lanes $T=$ control individuals; lanes $D=$ patient III; lanes $S=$ patient IIII.

$11 \mathrm{q} 21$ for one of the two homologous chromosomes 11 (Fig. 3B). In order to define more precisely the region rearranged, markers spanning the region between 11p15.1 (D11S834) and the centromere (D11Z1) were also used on metaphases from patient III1. As shown in Table 1, the signals corresponding to the markers D11S781, FAT5, D11S324, WT1, and D11S87 were translocated on the long arm of chromosome 11 for individuals I1 and I2, and were absent in patients III and IIII. Normal signal locations were obtained with the other telomeric and centromeric flanking markers.
Using polymorphic markers and chromosomal in situ suppression hybridization (CISS) we have demonstrated that in one pedigree two related cases of (W)A(GR) associated with a deletion of $11 \mathrm{p} 13-\mathrm{p} 14$ resulted from the transmission of a pericentric intrachromosomal insertion of the WAGR region in three members (I1, I2, II2) and probably in the mother or father of I1 and I2. CISS and RFLP analysis enabled us to determine the boundaries of the insertion/deletion. Although complicated alternative pachytene diagrams can be constructed for this type of rearrangement (Madan and 

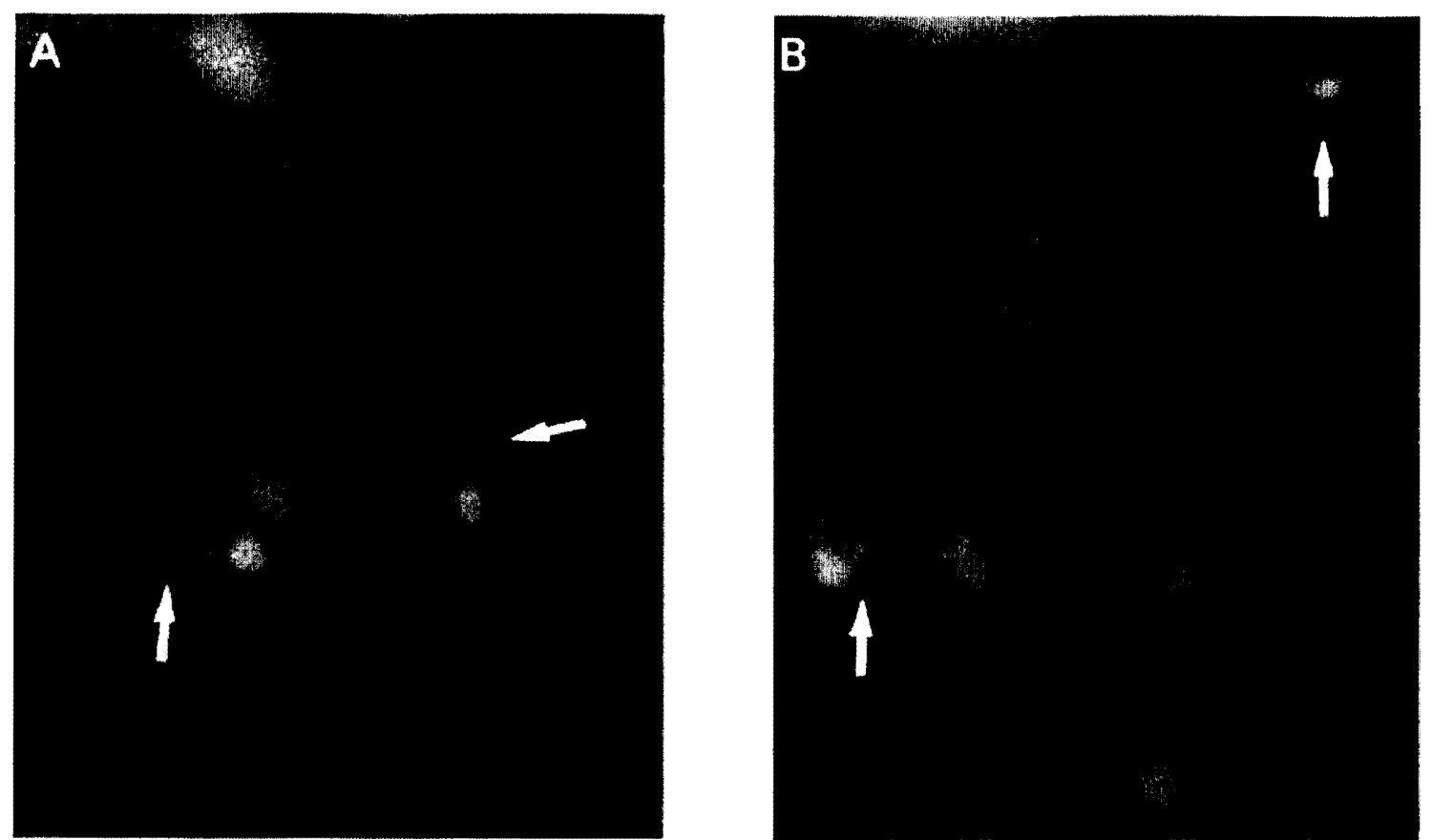

Figure 3. Representative in situ hybridization. A: Hybridization of probes DIIS78I (cosmid in the WAGR region) and $D|| Z \mid$ (centromere-specific probe for chromosome II) to metaphases from individual 12. On the right, the normal chromosome 11 with cosmid signal on band p 13-p14.1. On the left, the rearranged chromosome || with D I IS781 signal on the proximal part of the long arm of chromosome $\mid 1$, and absence of the signal on I|p|3-p|4.1. B: The same probes, hybridized to metaphase chromosomes from patient II3. On the left, the normal chromosome II; and on the right, the rearranged chromosome II showing deletion of DIIS78|.

Menko, 1992), in the most simple explanation the deleted chromosome 11 is the result of a homologous pairing that excluded the inserted segment and its homolog on the normal chromosome 11. A single crossover (or any uneven number of crossovers) between these segments will give two recombinant chromosomes: one with a deletion and one with a duplication of the WAGR region. Madan and Menko (1992) reviewed 27 cases of intrachromosomal insertions and gave a general risk of $15 \%$ for children to inherit an unbalanced karyotype. In this case the risk might be higher because of the viability of conceptus with either a deletion or a duplication of the WAGR region (Lavedan et al., 1989).

Among the 71 WAGR syndromes reported, 54 (76\%) were sporadic cases with de novo rearrangements of $11 \mathrm{p} 13$ and $15(21 \%)$ were familial cases. The size of the deletion is variable (Junien and van Heyningen, 1991). One sporadic case of $\operatorname{del}(11)(\mathrm{p} 13)$ in the mosaic state $(50 \%)$ was described by Nakagome and Nagahara (1985). This mosaicism could be the result of an early postzygotic rearrangement. Most of the de novo rearrangements are of paternal origin (Huff et al.,
1990). Among the 15 familial cases described, the nature of the rearrangement was determined in 6. Five resulted from a balanced insertion of band 11 p13 into another chromosome (Hittner et al., 1979; Koussef, 1981; Yunis and Ramsay, 1980; Lavedan et al., 1989; Prieur, 1989), one from a ring chromosome inherited from the mother with a mosaic 47,XX,del(11)(p11p15), $+\mathrm{r}(11)(\mathrm{p} 11 \mathrm{p} 15) /$ $46, X X, \operatorname{del}(11)(p 11 p 15)$ (Mannens et al., 1991). They all involved maternal inheritance except one case of insertion (Lavedan et al., 1989). Altogether these observations suggest that the asymptomatic carriers presented with an apparently balanced rearrangement. The deletion could be of paternal or maternal origin without differences in the expression of the syndrome. In the family reported here, both affected individuals with complete and incomplete forms of WAGR had inherited the deleted chromosome, including the gene for both $W T 1$ and FAT5, a candidate sequence for aniridia, via the maternal germline. The incomplete penetrance observed in WAGR patients is thus not correlated with the parental origin of the inherited rearranged chromosome. Together with the demonstration of a biallelic expression of the WTI gene 
(Zhang and Tycko, 1992), our results do not argue in favor of imprinting as an explanation for the variable expressivity in WAGR cases.

Interestingly, the patient with the more severe WAGR syndrome, including pseudohermaphroditism, had the karyotype $46, \mathrm{XY}, \operatorname{del}(11)(\mathrm{p} 13)$. The less severely affected patient was a girl with exactly the same deletion, $46, \mathrm{XX}, \operatorname{del}(11)(\mathrm{p} 13)$. The observation of proteinuria and glomerular sclerosis in patient II3 is reminiscent of Drash syndrome for which specific point mutations in WT1 have been described. As proposed by Pelletier and coworkers (1991a, b), these mutations in exons 9 and 8 could have negative dominant effects and be more deleterious than the loss of one WTI allele. It is however, interesting that patient II3 with deletion of WT1 presented features similar to those of the Drash syndrome. Since most cases of Drash syndrome are children with a $46, \mathrm{XY}$ karyotype and ambiguous genitalia, the presence of the $\mathrm{Y}$ chromosome and either a mutated or a deleted allele of WT1 has a more serious effect on external and internal gonad development.

The combined use of polymorphic markers and CISS thus proved to be a powerful tool to characterize a complex rearrangement undetectable by classical cytogenetic methods.

\section{ACKNOWLEDGMENTS}

This work was supported by I.N.S.E.R.M., the Ministère de la Recherche et de la Technologie, the Ligue Nationale contre le Cancer, the Association de Recherche Contre le Cancer, and the Netherlands Cancer Foundation (Koningin Wilhelmina Fonds) grant IKA 89-30. The collaboration was facilitated by Commission of the European Economic Communities grant SCI*0469-c (EDB). We wish to thank R. van der Voort and J. Visser for technical assistance.

\section{REFERENCES}

Call KM, Glaser T, Ito CY, Buckler AJ, Pelletier J, Haber DA, Rose EA, Kral A, Yeger H, Lewis WH, Jones C, Housman DE (1990) Isolation and characterization of a zinc finger polypeptide gene at the human chromosome 11 Wilms' tumor locus. Cell 60:509-520.

Francke U, Holmes LB, Atkins L, Riccardi VM (1979) AniridiaWilms' tumor association: Evidence for specific deletion of 11p13. Cytogenet Cell Genet 24:185-192.

Gessler M, Poutska AM, Cavenee W, Neve RL, Orkin SH, Bruns GAP (1990) Homozygous deletion in Wilms' tumour of a zincfinger gene identified by chromosome jumping. Nature 343:774778

Haber DA, Buckler AJ, Glaser T, Call KM, Pelletier J, Sohn RL, Douglass EC, Housman D (1990) An internal deletion within an $11 \mathrm{pl} 3$ zine finger gene contributes to development of Wilms tumor. Cell 61:1257-1269.

Harrisson-Lavoie K, John R, Porteous D, Little P (1989) A cosmid clone map derived from a small region of human chromosome 11. Genomics 5:501-509.

Heding IJJP, Ivens AC, Wilson J, Strivens M, Gregory S, Hoovers JMN, Mannens M, Redeker B, Porteous D, van Heyningen V,
Little PFR (1992) The generation of ordered sets of cosmid DNA clones from human chromosome 11 . Genomics 13:89-94.

Hittner HM, Riccardi VM, Francke U (1979) Aniridia due to chromosome 11 deletion. Ophthalmology 86:1173-1183.

Hoovers JMN, Mannens M, John R, Bliek J, van Heyningen V, Porteous D, Leschot NJ, Westerveld A, Little PFR (1992) High resolution localization of 69 potential human zinc-finger protein genes: A number are clustered. Genomics 12:254-263.

Huff V, Meadows A, Riccardi VM, Strong LC, Saunders GF (1990) Parental origin of de novo constitutional deletions of chromosomal band 11p13. Am J Hum Genet 47:155-160.

Junien C, van Heyningen V (1991) Report of the Committee on the Genetic Constitution of Chromosome 11. Human Gene Mapping 11. Cytogenet Cell Genet 58:459-555.

Koussef BG (1981) Aniridia Wilms tumor association. J Pediatr 98: 676-677.

Lavedan C, Barichard F, Azoulay M, Couillin P, Molina-Gomez D, Nicolas H, Quack B, Rethoré MO, Noel B, Junien C (1989) Molecular definition of de novo and genetically transmitted WAGR-associated rearrangements of $11 \mathrm{p} 13$. Cytogenet Cell Gener 50:70-74.

Lichter P, Tang CC, Call K, Hermanson G, Evans GA, Housman $D$, Ward $C$ (1990) High resolution mapping of human chromosome 11 by in situ hybridization with cosmid clones. Science 247:64-69.

Madan K, Menko FH (1992) Intrachromosomal insertions: A case report and a review. Hum Genet 89:1-9.

Mannens M, Hoovers JM, Bleeker-Wagemakers EM, Redeker B Bljek J, Overbeeke-Melkert M, Saunders G, William B, van Heyningen V, Junien C, Haber D, Speleman F, Heyting C, Slater RM, Leschot NJ, Westerveld A (1991) The distal region of $11 \mathrm{p} 13$ and associated genetic diseases. Genomics 11:284-293.

Nakagome Y, Nagahara N (1985) High-resolution studies in patients with aniridia-Wilms' tumor association. Hum Genet 70:289.

Pelletier J, Bruening W, Frederick PL, Haber DA, Glaser T, Hous. man DE (1991a) WT1 mutations contribute to abnormal genital system development and hereditary Wilms' tumour. Nature 353: 431-434.

Pelletier J, Bruening W, Kashtan CE, Mauer SM, Manivel JC. Striegel JE, Houghton DC, Junien C, Habib R, Fouser L, Fine RN, Silverman BL, Haber DA, Housman D (1991b) Germline mutations in the Wilms' tumor suppressor gene are associated with abnormal urogenital development in Denys-Drash syndrome. Cell 67:437-447.

Prieur F (1989) Délétion 11p13 récurrente dans une généalogie avec expression phenotypique chez les deux enfants. Thèse de Médecine, Université de Saint-Etienne, 134 p.

Pritchard-Jones K, Fleming S, Davidson D. Bickmore W, Porteous D, Gosden C, Bard J, Buckler A, Pelletier J, Housman D, van Heyningen V, Hastie N (1990) The candidate Wilms' tumour gene is involved in genitourinary development. Nature 346:194gene

Rose EA, Glaser T, Jones C, Smith CL, Lewis WH, Call KM, Minden $M$, Champagne E, Bonerta L, Yeger $H$, Housman D (1990) Complete physical map of the WAGR region of $11 \mathrm{p} 13$ localizes a candidate Wilms' tumor gene. Cell 60:495-508.

Ton CCT, Hirvonen $H$, Miwa $H$, Weil MM, Monaghan $P$, van Heyningen V, Hastie ND, Collins F, Swaroop A, Strong LC, Saunders GF (1992) Positional cloning and characterization of a paired box and homeobox-containing gene from the aniridia region. Cell 67:1059-1074.

van Heyningen V, Bickmore WA, Seawright A, Fletcher JM, Maule J, Fekete G, Gessler M, Bruns GAP, Huerre-Jeanpierre C, Junien C. Williams BRG (1990) Role for Wilms' tumor gene in genital development. Proc Natl Acad Sci USA 87:5383-5386.

van Heyningen V, Jordan T, Monoghan P, Hanson I, Fantes J, Hastie ND, Ton CCT, Saunders G (1992) Isolation and characterization of a candidate gene for the aniridia locus, AN2. Cytogenet Cell Genet (in press).

Wadey RB, Little PFR, Pritchard J, Cowell JK (1990) Isolation and regional localization of DNA sequences from a human chromosome 11 specific cosmid library. Hum Genet 84:417-423.

Waye JS, Creeper LA, Willard HF (1987) Organization and evolution of alpha satellite DNA from human chromosome 11. Chromosoma 95:182-188.

Yunis JJ, Ramsay NKC (1980) Familial occurrence of the aniridia Wilms tumor syndrome with deletion 11p13-14.1. J Pediatr 96: $1027-1030$.

Zhang Y, Tycku B (1992) Monoallelic expression of the human H19 gene. Nature Genet 1:40-44. 